\title{
EDITORIAL
}

\section{Associate editor reflections on the Progress in and Future of strategic management research in Journal of Management \& Organization}

\section{INTRODUCTION}

In my previous editorial (O'Shannassy, 2015), I highlighted the important role strategic management research and the work of strategy practitioners plays in improving the performance of organizations to the satisfaction of shareholders and stakeholders, the practice of strategy work, the well-being of society and our quality of life. Review of recent media articles (e.g., Gottliebsen, 2017; Rogers, 2017; Stuart Hunter, 2017) highlights the importance of effective strategic management for the well-being of the global financial system, effective management of the healthcare sector including the health insurance sector for all countries, the practice of innovation, the evolution of technology (Rogers, 2017) and sustainability (O’Shannassy, 2015).

Hambrick (2004: 91) observes that the focus of the field of strategic management is to 'study the roles and responsibilities of general managers' and avoid being taken over by 'microeconomics, organizational sociology, marketing and psychology'. The term general managers has been interpreted broadly by the field of research since the late 1970s. Mintzberg (1994) made a strong point that strategic management performed effectively is much more than about the work of the chief executive officer on his or her own managing the strategy context, processes and content. There has been since the 1980s an increasing appreciation of the strategy work of top managers inspiring and working with internal and at times external strategists (i.e., management consultants), and middle-line managers to achieve better strategic thinking and innovation outcomes (Mintzberg, 1994; Tushman \& O’Reilly, 1997). These strategy workers are required to work together to efficiently harness organization resources deployed at the network-level, corporate-level, business-level and functional-level in human resources, marketing, finance, information technology and operations for the firm to succeed. How strategy workers do this varies from firm to firm and industry to industry (Hart, 1992; O'Shannassy \& Hunter, 2009). This is what we study.

Strategic management plays a crucial role in big business, the small and medium-size enterprise (SME) sector, the private sector, the public sector and the not-for-profit sector. Strategic management is equally vital to the performance and success of the big business executive, the SME general manager, the new venture entrepreneur and the not-for-profit general manager to provide a contrast of the influence of the field and where it is applied. Firm size does have an important impact on the strategic choices made by the general manager - see Merchant (2014) for a wider discussion. If we as a community of academics deliver quality, relevant and useful research findings and then disseminate these findings with impact across the community, our work can inform the future work of general managers and improve outcomes for their constituents including shareholders, employees, customers and the wider community. This is how we make a difference.

Journal of Management \& Organization $(J M O)$ is pleased to present here the strategic management themed issue for 2017. In terms of a roadmap for this editorial the next section presents this year's eclectic mix of six research articles that reflect the range of interests of scholars in our field. Following the remarks on these articles the editorial presents a summary and synthesis of 20 strategic management research articles published in $J M O$ since my editorial in the previous strategic management themed issue in Volume 21, Issue 5 from 2015 with supporting comments and reflections. In helping our 
community of strategic management scholars better understand the direction we have been going, as well as where the research gaps are, this editorial here can help to guide and position future research. Future directions for research from thought leaders is then presented to help to broaden our perspective on where we can take strategic management research that is international in orientation with an Australasian edge; this is followed by the Conclusion section.

\section{THE STRATEGIC MANAGEMENT THEMED ISSUE}

Six new articles are presented here in this issue. In total five of these articles use quantitative methods; the fifth article presented here is the only article to use qualitative case study methods. This does not indicate a methodological or methods preference from the Editorial Board of $J M O$ or Associate Editors looking after strategic management research at $J M O$ - simply a case of more quantitative oriented articles submitted to $J M O$, surviving the review process and being available for publication. One of the strengths of our journal is that we equally consider quantitative research methods, qualitative research methods and theory development. Theories presented here include upper echelons and top management teams (TMTs), alliances, and mergers and acquisitions (M\&A), the resource-based view, the knowledge-based view and the explore-exploit tension in innovation.

In the first article, Lin and Dang (2017) study the relationship between strategic consistency and organization performance using cross-sectional data from 439 Taiwan stock exchange listed electronics companies for 2010 and 2011. A focus of this study for Lin and Dang (2017) is the moderating influence of variables including organizational slack, environmental dynamism and TMT attributes (i.e., tenure and heterogeneity) with strategic consistency using the subgroup analysis method with multiple regression. There are three generic strategy dimensions used for the study for strategic consistency - low cost, marketing differentiation and technology differentiation. The dependent variable used is a composite average of return on equity, return on assets and return on sales. In the findings strategic consistency and the high organizational slack group, the low environmental dynamism group, high TMT tenure and low TMT tenure heterogeneity all predict better organization performance.

Next Li (2017) gathers data with 1005 observations from 335 electronics companies in Taiwan over a 3-year period from 2007 to 2009 in relation to TMT knowledge and experience and predicting strategic decisions and organization performance. Ordinary least squares regression is used for the analysis. The results find a positive relationship between international experience and the innovation dependent variable measured by research and development intensity. There was a positive relationship between international experience and firm internationalization (measured by the number of foreign subsidiaries). Innovation also has a positive influence on internationalization.

Kim and Jin (2017) then examine the influence of structural embeddedness and vertical resource relatedness on firm governance choice, with the governance choice being alliances or a M\&A approach. They define structural embeddedness as when network partners are in the same network cluster due to relational embeddedness (i.e., cohesive ties and information sharing) and positional embeddedness (i.e., centrality of network position and social construction of status in the network). Kim and Jin (2017) define vertical resource relatedness as the extent that a firm can use the products or services of another firm as an input for its own production or supply output. They use the SDC Platinum and COMPUSTAT databases to develop a final sample of 654 observations (181 M\&A and 473 alliances) in the US hardware and software industries. The probit model is used for the analysis. Structural embeddedness is found to be a predictor of governance choice. Partial support was found for structural embeddedness increasing the probability of choosing M\&A over an alliance governance approach; vertical resource relatedness increases the probability of M\&A being chosen in preference to alliance governance. 
Ghosh (2017) studies the relationship between corporate social performance, industry and corporate reputation. Data were collected from 220 organizations listed on the Bombay Stock Exchange in India from 11 industries. The data is analysed using moderated regression analysis. The study finds that industry sector moderates the relationship between corporate social performance and corporate reputation more strongly in industries where social and environmental issues are prominent. The relationship between social performance and corporate reputation varies according to the types of social performance - community performance, environmental performance and employee performance.

Next Smith, Gilbert, and Sutherland (2017) present a grounded theory case study of an Asia-Pacific subsidiary of a global professional services firm managing the classic innovation conundrum of exploring new sources of innovation while exploiting current service offerings. Using a theoretical sampling approach (i.e., selecting interviewees on the basis of need for the analysis) 32 interviews were undertaken with a cross-section of senior partners, innovation directors, project leaders and managers. The case study findings indicate a three-tiered approach to organization form with heavy exploitation activity sitting alongside deep exploration projects - this required a high-level tolerance of uncertainty in the firm while these competing tensions are managed. Clear communication down through the organization from the chief executive officer and chief strategy officer plays an important role in motivating and focussing the organization's exploratory innovation initiative.

Finally, Chen, Lee, and Chen (2017) present a quantitative study of the relationship between innovation and organization performance sampling 147 agrifood firms and 212 private firms. In this study absorptive capacity - the capacity to learn and absorb knowledge is theorized to be vital to the success of innovation efforts. Presenting a structural model the research finds a positive relationship between relational alignment, technological alignment, marketing alignment and absorptive capacity. The structural model also evidences a positive correlation between absorptive capacity and competitive sustainable advantage.

\section{STRATEGIC MANAGEMENT RESEARCH IN JOURNAL OF MANAGEMENT \& ORGANIZATION SINCE THE 2015 EDITORIAL}

Next, I present Table 1 which summarizes strategic management research in JMO since my editorial in Volume 21, Issue 5. Articles were selected on the basis of topic focus on one or more of the following strategic management research areas: corporate governance, the board of directors, the chief executive officer, top managers, middle-line managers, strategy workers, network level, corporate level, business level, mission/vision/strategic intent, innovation, strategic change, strategy vocabulary and organization performance. In total, 20 articles are included in Table 1 from the 86 published in JMO for this period; 14 of these articles use quantitative methods, four use qualitative methods and two focus on literature review and theory development.

The theoretical focus of the manuscripts in Table 1 was varied evidencing good breadth within the field of research. Notable trends to mention here included innovation being the most popular topic area with five articles. Four articles considered TMT issues including Sanchez-Famoso, Maseda, and Iturralde (2017) who made a connection between TMT characteristics, family business practice and innovation. Several articles (e.g., O’Shannassy, 2016; Zhou, Zhou, Feng, \& Jiang, 2017) had an inside the firm focus drawing on theories including the resource-based view, knowledge-based view and dynamic capabilities. Industry dynamics was the focus for Lehmberg (2017) and corporate governance for Liu, Valenti, and Yi-Jung (2016).

In relation to the quantitative research in Table 1, JMO published six articles prepared by Taiwanese researchers, two from Spain, one each from a Chinese research team, South Korea, Italy, Canada, the United States and India. There was a strong Asian influence here with nine of the 14 articles reporting Asian research, three articles reporting European research, one Canadian research 
Table 1. Strategic management research in Journal of Management \& Organization from Volume 21, Issue 62015,2016 and 2017

\begin{tabular}{|c|c|c|c|c|c|}
\hline Author(s) & Year & Focus of the study & Sample size & Method & Key findings \\
\hline Wang & 2015 & $\begin{array}{l}\text { Top management team and } \\
\text { alliance formation in Taiwan }\end{array}$ & 981 firms & Binomial regression & $\begin{array}{l}\text { Using panel data from } 2007 \text { to } 2011 \text { the study finds that } \\
\text { TMTs with qualifications from a prestigious university or } \\
\text { prior prestigious employment affiliations assists the } \\
\text { formation of strategic alliances in an international } \\
\text { business setting. }\end{array}$ \\
\hline Song, Makhija, and Kim & 2015 & $\begin{array}{l}\text { International investment } \\
\text { decisions in uncertain } \\
\text { business conditions }\end{array}$ & Not applicable & Literature review & $\begin{array}{l}\text { There is need for development of a wider range of } \\
\text { environmental uncertainty measures for international } \\
\text { business research. The costs and values of real options } \\
\text { under consideration should be thought through }\end{array}$ \\
\hline Huang and Chu & 2015 & $\begin{array}{l}\text { Co-opetition strategies in SME } \\
\text { accounting firms in Taiwan }\end{array}$ & 225 accountants & $\begin{array}{l}\text { Structural equation } \\
\text { modelling (SEM) }\end{array}$ & $\begin{array}{l}\text { Professional expertise heterogeneity has a positive } \\
\text { influence on competition. Complementary professional } \\
\text { expertise has a positive influence on cooperation }\end{array}$ \\
\hline Wei and Lin & 2015 & $\begin{array}{l}\text { Intangible assets and } \\
\text { organizational effectiveness in } \\
\text { Taiwan }\end{array}$ & 398 companies & $\begin{array}{l}\text { Moderated multiple } \\
\text { regression }\end{array}$ & $\begin{array}{l}\text { Using } 4 \text { years of panel data the study finds that human } \\
\text { capital and environmental pressure jointly predict } \\
\text { organization effectiveness }\end{array}$ \\
\hline Ripollẻs and Blesa & 2016 & $\begin{array}{l}\text { Interfirm network management } \\
\text { in Spain }\end{array}$ & 400 companies & SEM & $\begin{array}{l}\text { Using survey data the study found the presence of a } \\
\text { mature or growing industry environment influences firm } \\
\text { network choices }\end{array}$ \\
\hline $\begin{array}{l}\text { Shahzad, Wales, } \\
\text { Sharfman, and Stein }\end{array}$ & 2016 & $\begin{array}{l}\text { Entrepreneurial orientation and } \\
\text { stakeholder value in the } \\
\text { United States }\end{array}$ & $\begin{array}{l}1015 \text { public } \\
\text { corporations }\end{array}$ & $\begin{array}{l}\text { Random-effects } \\
\text { regression }\end{array}$ & $\begin{array}{l}\text { A significant relationship is found between the three } \\
\text { dimensions of entrepreneurial orientation (i.e., } \\
\text { innovation, risk taking, proactiveness) and stakeholder } \\
\text { value }\end{array}$ \\
\hline Farnese, Fida, and Livi & 2016 & $\begin{array}{l}\text { Reflexivity, flexibility and } \\
\text { innovation in Italy }\end{array}$ & 357 & $\begin{array}{l}\text { Moderated multiple } \\
\text { regression }\end{array}$ & $\begin{array}{l}\text { Reflexivity and flexibility have a complimentary joint effect } \\
\text { on innovation outcomes }\end{array}$ \\
\hline Pichlak & 2016 & Innovation adoption in Poland & 264 & Delphi survey & $\begin{array}{l}\text { Top manager attitude and access to appropriate human } \\
\text { resources has a positive influence on all stages of the } \\
\text { innovation adoption process }\end{array}$ \\
\hline Zakrzewska-Bielawska & 2016 & $\begin{array}{l}\text { Mutual influence of strategy and } \\
\text { structure in Poland }\end{array}$ & 61 companies & $\begin{array}{l}\text { Closed-interview } \\
\text { questionnaire }\end{array}$ & $\begin{array}{l}\text { In the exploration phase CEOs see structure as having } \\
\text { more influence than strategy. In the exploitation phase } \\
\text { strategy has a stronger influence than structure }\end{array}$ \\
\hline O'Shannassy & 2016 & $\begin{array}{l}\text { The research construct strategic } \\
\text { intent }\end{array}$ & Not applicable & Literature review & $\begin{array}{l}\text { Three dimensions of the strategic intent construct are } \\
\text { identified - shared vision, foresight and resource focus. } \\
\text { The CEO plays the key role in developing and } \\
\text { communicating strategic intent }\end{array}$ \\
\hline Liu, Valenti, and Yi-Jung & 2016 & $\begin{array}{l}\text { Governance practice, family } \\
\text { ownership status and } \\
\text { information disclosure in Taiwan }\end{array}$ & 516 companies & $\begin{array}{l}\text { Generalized least } \\
\text { squares random- } \\
\text { effects regression }\end{array}$ & $\begin{array}{l}\text { Using } 5 \text { years of data giving } 2,580 \text { cases the study found } \\
\text { that family ownership and board independence jointly } \\
\text { predict information disclosure quality }\end{array}$ \\
\hline $\mathrm{Li}$ & 2016 & $\begin{array}{l}\text { TMT experience and } \\
\text { knowledge, strategic } \\
\text { decisions and organization } \\
\text { performance in Taiwan }\end{array}$ & 335 companies & $\begin{array}{l}\text { Ordinary least } \\
\text { squares (OLS) } \\
\text { regression }\end{array}$ & $\begin{array}{l}\text { There was a positive relationship between the } \\
\text { heterogeneity of the functional background of TMT } \\
\text { members and innovation outcomes. The international } \\
\text { experience of the TMT correlated positively with } \\
\text { innovation outcomes and internationalization }\end{array}$ \\
\hline Han, Jo, and Kang & 2016 & $\begin{array}{l}\text { Knowledge overlap and } \\
\text { innovation }\end{array}$ & $\begin{array}{l}192 \text { technological } \\
\text { M \& As }\end{array}$ & $\begin{array}{l}\text { Negative binomial } \\
\text { regression }\end{array}$ & $\begin{array}{l}\text { In this South Korean study a high quality of knowledge } \\
\text { overlap in technological M\&A has a positive influence } \\
\text { on innovation performance; lack of knowledge overlap }\end{array}$ \\
\hline
\end{tabular}


Zhou, Zhou, Feng, and Jiang

2017

Dynamic capabilities, innovation 204 and performance in China

Knowledge networks and innovation performance in Taiwan

Dominguez-CC and Barroso-Castro

Lehmberg

Lakshman, Kumra, and Adhikari

Sanchez-Famoso, Maseda, and Iturralde

Managerial change leading to

strategic change

dustry exit process in Japan

2017 Market orientation, intrafirm causal ambiguity and innovation in India

2017 TMT, family business, social capital and innovation in Spain

Chowman, Pries, and 2017

Innovation, human resource management, work organization and strategy in Canada

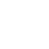

ve

Partial least squares SEM

Qualitative interview

Case studies

\section{0 middle}

managers Partial least squares
SEM

2,326 work places OLS regression

(1)


(Chowman, Pries, and Mann, 2017) and one US research (Shahzad, Wales, Sharfman, and Stein, 2016). The most favoured quantitative method was structural equation modelling (SEM) used in four articles with partial least squares SEM and structural equation modelling used in a further two articles. Moderated regression analysis was used in two articles, ordinary least squares regression used in two articles and other regression analysis techniques (e.g., binomial regression, generalized least squares random-effects regression) used in a further four articles. The observation here is that the popularity of our journal with Asian researchers skilled in quantitative methods is having a positive influence on the successful publishing of quantitative strategic management research in JMO.

In the qualitative articles Pichlak (2016) used a Delphi survey which made extensive use of counts and descriptive statistics in the analysis, Zakrzewska-Bielawska (2016) used a closed-interview questionnaire, the Dominguez-CC and Barroso-Castro (2017) analysed news items, company reports and company documents, and Lehmberg (2017) developed a case study. Two of these studies report Polish research, one study was conducted in Spain and the fourth paper was a Japanese case study written by a US researcher. This indicates that there is scope for researchers skilled in qualitative methods to have a bigger publishing impact in $J M O$, especially Australian and New Zealand researchers.

The question arises in relation to the progress of strategic management research in JMO: Have we achieved international in orientation with an Australasian edge? (Bentley, 2015). The evidence presented here in Table 1 indicates we have clearly achieved an international orientation. There is scope for a stronger level of publishing by Australian and New Zealand strategic management researchers in $J M O$, particularly using qualitative research methods. So there is more to do here in progressing the research agenda articulated by Galvin and Arndt (2014), Bentley (2015) and O'Shannassy (2015) in previous editorials. Authors would do well to take note of the tips and advice shared in each of these editorials when commencing research projects and preparing manuscripts for publication.

\section{OBSERVATIONS ON CAUSES OF PUBLICATION SUCCESS AND FAILURE FOR AUTHORS}

Some Associate Editor observations on the causes of success and failure of submissions over the past 2 years follow next. I will first discuss the importance of 'signalling to the reader' by the author(s) in the cover letter, abstract and use of keywords. Second I will discuss arrangement of the body of the manuscript. These comments are directed especially to doctoral students and early career researchers looking to publish in JMO.

In relation to effective 'signalling to the reader' first there is need for authors to prepare a well-crafted cover letter that indicates where the manuscript is positioned in relation to the published literature, the key focus of the study, the unique and important features of the study and the overall contribution. Second authors should choose keywords for articles carefully and wisely including the keywords that capture the core construct or constructs examined in the study and some insight into the method used; time and again articles are submitted with poorly chosen keywords with no insight into method used in the study evident. The outcome of poor choice of keywords is difficulty locating reviewers interested in the manuscript to work through what can be two to on occasion five rounds of reviews. Third, a smart edgy title can help to draw attention to the manuscript, especially when the ideas and research constructs conveyed by the title are reinforced when reading the abstract and more broadly the manuscript. Fourth, successful submissions have a well-written abstract that captures the essence of the contribution of the article and provides an indication of potential impact on the research area. There should be synergy apparent to the reader from these 'signals' from the author(s).

In relation to preparation of the body of the manuscript the signals provided by the author(s) to the Editor-in-Chief, Associate Editor and Reviewer(s) in the cover letter, keywords, title and Abstract should be reinforced with what follows. The Introduction section should be approximately two pages 
and highlight the topic area, the core argument, the research question(s) to be explored and give a roadmap of the manuscript. The Literature Review section with theory development should be wellorganized showcasing a prudent, well selected and well prioritized choice of literature - it is especially important to leverage off the leading researchers in the theoretical and/or empirical literature to which you are trying to make a contribution (e.g. Taniman \& O'Shannassy, 2015). Any hypotheses that are presented should be well supported in the preceding remarks to their presentation with appropriate use of literature, development of theory and explanation of research constructs. There is need for hypotheses to be carefully crafted for the test using key words that describe if that $a$ happens then $b$ happens' in terms of the research constructs that will appear in the later statistical analysis; the wording of the hypotheses should be lean, succinct and interesting. See Whetten (1989) on good theory development. In the Methods section the sample should be appropriate to demonstrate the robustness of the quantitative or qualitative technique applied, and that research method should be applied with precision with the results displayed in appropriate tables and figures in JMO format. Tables and figures not in JMO format are a red flag for the Editor-in-Chief, Associate Editors and reviewers. Write-up of results should follow JMO customs for the method applied - if in doubt the next journal to view for guidance is Academy of Management Journal; too often tables and figures are poorly presented and/or write-up is not clear and accurate. This has the effect of reducing the confidence of the Associate Editors and the reviewers in the empirical analysis that is presented - another reason to 'reject' an article. Discussion should state the theoretical implications, practical implications, limitations and future research agenda; weaker manuscripts submitted to JMO fail to develop substantial remarks in one or more of these areas. Finally, the Conclusion section should highlight the contribution you have made to the literature.

\section{FUTURE RESEARCH DIRECTIONS FROM STRATEGIC MANAGEMENT THOUGHT LEADERS}

There is an argument that the widening domain of the strategic management research field reflects the range of challenges and issues confronting practicing managers (Durand, Grant, \& Madsen, 2017). There also remains scope to improve academic standards in theory development and application of research methods (Whetten, 1989; Durand, Grant, \& Madsen, 2017). The purpose of this section is to bring together insight from thought leaders in the field on future research directions.

The currency and relevance of the research agenda communicated in Galvin and Arndt (2014), Bentley (2015) and O'Shannassy (2015) remains relevant to our journal today. Strategic management does have a wide range of eclectic research streams including corporate-level strategy, business-level strategy, strategic leadership, strategy process, strategy practice, global strategy, institutional strategy, competitive dynamics, cooperative strategy (i.e., network alliances), industry dynamics, industry evolution, innovation strategy, technology strategy, stakeholder theory, behavioural strategy, the resource-based view of the firm and the knowledge-based view of the firm (Durand, Grant, \& Madsen, 2017). The field is not converging around a particular theoretical base; however, it does tend to follow research traditions in areas such as agency theory, industrial economics, transaction costs and the resource-based view of the firm (Durand, Grant, \& Madsen, 2017). Each of these interest areas in strategic management has its own subtleties and nuances in relation to a future research agenda which is beyond the scope of this editorial here, however certain over-arching observations on future research priorities can be made.

The first observation is the importance of relevance to practice and practical application. The primary focus of the research should be on the organization and the tasks and challenges of general managers (Hambrick, 2004). Organizations differ in how they create value between industries and within industries; understanding the source of better firm performance and the interests of shareholders and stakeholders is paramount and this should be explored. Firm size, firm age, industry clock speed and time are important influences in strategy research with different effects in different industries and with different technologies 
(Mosakowski \& Earley, 2000). From a practice perspective we are interested in how strategy workers actually work together and communicate (i.e., discourse, job descriptions, gestures, body language, PowerPoint, report writing, board papers) 'day-to-day', in board meetings, team meetings and strategy workshops (Jarzabkowski, Kaplan, Seidl, \& Whittington, 2016; O’Shannassy \& Leenders, 2016). Creating new strategy vocabulary to explain new phenomena and adding to clarity of definitions and concepts is encouraged (Schmitt, Raisch, \& Volberda, 2016). Intermediate organization outcomes such as innovation capability, competitive intensity, status, reputation and legitimacy are all of interest (Durand, Grant, \& Madsen, 2017). Industry dynamics, industry evolution and the development of new business models is having a big impact in industries such as motor vehicles (e.g., Tesla and the electronic motor vehicle; Ford Motor Company interest in artificial intelligence), telecommunications (i.e., industry clock speed and mobile phones) and robotics (Rogers, 2017).

Second, Arora, Gittelman, Kaplan, Lynch, Mitchell, and Siggelkow (2016) highlight the value of applying new research methods used in other research fields (e.g., geography and spatial data analysis; anthropology and video ethnography; criminology and group-based trajectories) to topics in strategic management research. This is not easy research to perform and publish successfully as the technique often requires some adaptation to allow the method to be applied with rigour in a different research field. Authors applying new methods in strategic management research should explain the translational work they have undertaken with the research technique applied, demonstrate its use, and then teach JMO readers how the technique can be used. These new methods can help to answer research questions that could not be answered before, or give more nuanced answers to matters that have been studied previously due to the enhancement in research technique (e.g., better accuracy of a measure) (Arora et al., 2016).

Finally, Bettis, Ethiraj, Gambardella, Helfat, and Mitchell (2016) draw attention to the value of replication to the field of strategic management research. Replication of studies can take a variety of forms. For example the robustness of a study can be tested using a different sample of data from big business in a different geographic location in the same industry, or in an small and mediumsize enterprise setting in the same geographic location in a different industry - there is a range of possibilities. Bettis et al. (2016) highlight the importance of the balance of evidence across studies, the significant $p$-values in particular studies are just as important to the development of the field of research as the nonsignificant studies - it is the balance of evidence across the studies that is important to consider. Equally this concept of replication of studies across firms of different size, in different geographic locations and/or in different industries can apply to the use quantitative methods, qualitative methods or mixed methods (O’Shannassy, 2015; Bettis et al., 2016).

\section{CONCLUSION}

This editorial has been wide ranging, taking stock of our own progress in $J M O$, show casing six new strategic management articles, making suggestions for existing and potential authors to consider on how the Associate Editor's see, read and assess the manuscripts submitted, and developing a future research agenda. The value of adopting new methods and replication or nonreplication of research findings has been highlighted. Strategic management research can and does make a difference to how we work and live, and this creates an exciting research and publishing opportunity for our community.

Timothy F. O’Shannassy

Senior Lecturer

Journal of Management \& Organization Graduate School of Business and Law

RMIT University

Melbourne, Australia 


\section{References}

Arora, A., Gittelman, M., Kaplan, S., Lynch, J., Mitchell, W., \& Siggelkow, N. (2016). Question-based innovations in strategy research methods. Strategic Management Journal, 37, 3-9.

Bentley, T. (2015). Editorial: Some thoughts from the new Editor-in-Chief. Journal of Management \& Organization, 21(1), 1.

Bettis, R., Ethiraj, S., Gambardella, A., Helfat, C., \& Mitchell, W. (2016). Creating repeatable cumulative knowledge in strategic management. Strategic Management Journal, 37, 257-261.

Chen, H. H., Lee, A., \& Chen, J. (2017). The relationship between innovation and performance in special non-profit firms: Social and cooperative agrifood firms. Journal of Management \& Organization. https://doi.org/10.1017/ jmo.2015.62.

Chowman, J., Pries, F., \& Mann, S. (2017). Persistent innovation and the role of human resource management practices, work organization, and strategy. Journal of Management \& Organization, 23(3), 456-471.

Dominguez-CC, M., \& Barroso-Castro, C. (2017). Managerial change and strategic change: The temporal sequence. Journal of Management \& Organization, 23(1), 46-73.

Durand, R., Grant, R., \& Madsen, T. (2017). The expanding domain of strategic management research and the quest for integration. Strategic Management Journal, 38, 4-16.

Fang, S. C., Wang, M. C., \& Chen, P. C. (2017). The influence of knowledge networks on a firm's innovative performance. Journal of Management \& Organization, 23(1), 22-45.

Farnese, M. L., Fida, R., \& Livi, S. (2016). Reflexivity and flexibility: Complimentary routes to innovation? Journal of Management \& Organization, 22(3), 404-419.

Galvin, P., \& Arndt, F. (2014). Strategic management: Building depth as well as breadth. Journal of Management \& Organization, 20(2), 139-147.

Ghosh, K. (2017). Corporate reputation, social performance, and organizational variablility in an emerging country perspective. Journal of Management \& Organization. https://doi.org/10. 1017/jmo.2016.25.

Gottliebsen, R. (2017, May 17). Going back to the 1950s for banking inspiration. The Australian, p. 31.

Hambrick, D. (2004). The disintegration of strategic management: It's time to consolidate our gains. Strategic Organization, 2(1), 91-98.

Han, J., Jo, G., \& Kang, J. (2016). Is high-quality knowledge always beneficial? Knowledge overlap and innovation performance in technological mergers and acquisitions. Journal of Management \& Organization. https://doi.org/10. $1017 /$ jmo.2016.35.

Hart, S. (1992). An integrative framework for strategy-making processes. Academy of Management Review, 17, 327-351.

Huang, H. C., \& Chu, W. (2015). Antecedents and consequences of co-opetition strategies in in small and mediumsized accounting agencies. Journal of Management \& Organization, 21(6), 812-834.

Jarzabkowski, P., Kaplan, S., Seidl, D., \& Whittington, R. (2016). On the risk of studying practices in isolation: Linking what, who, and how in strategy research. Strategic Organization, 14(3), 248-259.

Kim, S., \& Jin, K. (2017). Organizational governance of inter-firm resource combinations: The impact of structural embeddedness and vertical resource relatedness. Journal of Management \& Organization. https://doi.org/10.1017/ jmo.2016.9.

Lakshman, C., Kumra, R., \& Adhikari, A. (2017). Proactive market orientation and innovation in India: The moderating role of intrafirm causal ambiguity. Journal of Management \& Organization, 23(1), 116-135.

Lehmberg, D. (2017). The process of industry exit in the Japanese context: Evidence from the flat panel display industry. Journal of Management \& Organization, 23(1), 92-115.

Li, P. Y. (2016). The impact of the top management teams' knowledge and experience on strategic decisions and performance. Journal of Management \& Organization. https://doi.org/10.1017/jmo.2016.24.

Lin, C. S., \& Dang, V. T. (2017). Untangling the relationship between strategic consistency and organizational performance: An empirical analysis of moderator variables. Journal of Management \& Organization. https://doi.org/ 10.1017/jmo.2016.50.

Liu, Y., Valenti, A., \& Chen, Y. J. (2016). Corporate governance and information transparency in Taiwan's public firms: The moderating effect of family ownership. Journal of Management \& Organization, 22(5), 662-679.

Merchant, H. (2014). Configurations of governance structure, generic strategy, and firm size: Opening the black box of value creation in international joint ventures. Global Strategy Journal, 4, 292-309.

Mintzberg, H. (1994). The rise and fall of strategic planning. London, UK: Prentice Hall. 
Mosakowski, E., \& Earley, P. (2000). A selective review of time assumptions in strategy research. Academy of Management Review, 25, 796-812.

O'Shannassy, T. (2014). Investigating the role of middle managers in strategy-making process: An Australian mixed method study. Journal of Management and Organization, 20(2), 187-205.

O'Shannassy, T. (2015). Editorial: Strategic Management special issue. Journal of Management \& Organization, 21(5), 551-557.

O'Shannassy, T. (2016). Strategic intent: The literature, the construct and its role in predicting organization performance. Journal of Management \& Organization, 22(5), 583-598.

O'Shannassy, T., \& Hunter, P. (2009). A management consultant's guide to how strategic architecture can improve and organisation's 'bottom line'. Singapore Management Review, 31(1), 33-47.

O'Shannassy, T., \& Leenders, MAAM. (2016). Avoiding the 'too comfortable in the saddle' syndrome: Obtaining high performance from the chairperson, CEO and inside directors. Journal of Business Research https://dx.doi.org/ 10.1016/j.jbusres.2016.05.011.

Pichlak, M. (2016). The innovation adoption process: A multidimensional approach. Journal of Management \& Organization, 22(4), 476-494.

Ripollẻs, M., \& Blesa, A. (2016). Development of interfirm network management activities: The impact of industry, firm age and size. Journal of Management \& Organization, 22(2), 186-204.

Rogers, C. (2017, May 17). 20,000 jobs on the line at Ford, The Australian, p. 25.

Sanchez-Famoso, V., Maseda, A., \& Iturralde, T. (2017). Family involvement in top management team: Impact on relationships between internal social capital and innovation. Journal of Management \& Organization, 23(1), 136-162.

Schmitt, A., Raisch, S., \& Volberda, H. (2016). Strategic renewal: Past research, theoretical tensions and future challenges. International Journal of Management Reviews. https://doi.org/10.1111/ijmr.12117.

Shahzad, A., Wales, A., Sharfman, M., \& Stein, C. (2016). Casting a wider performance net: The role of entrepreneurial orientation in boosting firm stakeholder value. Journal of Management \& Organization, 22(2), 272-290.

Song, S., Makhija, M., \& Kim, S.M. (2015). International investment decisions under uncertainty: Contributions of real options theory and future directions. Journal of Management \& Organization, 21(6), 786-811.

Smith, A., Gilbert, D., \& Sutherland, F. (2017). The explore-exploit tension: A case study of organizing in a professional services firm. Journal of Management \& Organization. https://doi.org/10.1017/jmo.2017.6.

Stuart Hunter, G. (2017, May 19). Unloved hedge funds post strong returns. The Australian, p. 30.

Taniman, C., \& O'Shannassy, T. (2015). Exploring the influence of Chief Executive Officer professional development and work context on organisation performance: A multi-theoretic perspective. Journal of Management \& Organization, 21(5), 675-694.

Tushman, M., \& O'Reilly, M. (1997). Winning though innovation. Boston, MA: Harvard Business School Press.

Wang, Y.K. (2015). The impact of prestigious top management team on international alliance formation: Evidence from Taiwanese electronics firms. Journal of Management \& Organization, 21(6), 835-852.

Wei, Y. C., \& Lin, Y. Y. (2015). Intangible assets and decline: A population ecology perspective. Journal of Management \& Organization, 21(6), 755-771.

Whetten, D. (1989). What constitutes a theoretical contribution. Academy of Management Review, 14(4), 490-495.

Zakrzewska-Bielawska, A. (2016). Perceived mutual impact of strategy and organizational structure: Findings from the high-technology enterprises. Journal of Management \& Organization, 22(5), 599-622.

Zhou, S., Zhou, A., Feng, J., \& Jiang, S. (2017). Dynamic capabilities and organizational performance: The mediating role of innovation. Journal of Management \& Organization. https://doi.org/10. 1017/jmo.2017.20. 